\title{
Cytokine Profile in Cases with Premature Elevation of Progesterone Serum Concentrations during Ovarian Stimulation
}

\author{
N. NIKOLETTOS ${ }^{1}$, B. ASIMAKOPOULOS ${ }^{1}$, F. KÖSTER ${ }^{2}$, B. SCHÖPPER ${ }^{2}$, CH. SCHULZ $^{2}$, \\ G. S. CAGLAR ${ }^{2}$, A. EFTHIMIADOU ${ }^{1}$, O. PAGONOPOULOU ${ }^{1}$, K. DIEDRICH ${ }^{2}$, \\ S. AL-HASANI ${ }^{2}$
}

${ }^{1}$ Laboratory of Physiology, School of Medicine, Democritus University of Thrace, Alexandroupolis, Greece and ${ }^{2}$ Department of Obstetrics and Gynecology, University Clinic Schleswig-Holstein, Campus Lübeck, Germany

Received October 2, 2006

Accepted January 29, 2007

On-line available February, 8, 2007

\begin{abstract}
Summary
The aim of this study was to investigate the concentrations of vascular endothelial growth factor (VEGF), basic fibroblast growth factor (bFGF), leptin, tumor necrosis factor-a, interleukin (IL)-1 $\beta$ and IL-6, in cycles with a premature rise of serum progesterone. 25 intracytoplasmic sperm injection (ICSI) cycles with (Group 1) and 25 ICSI cycles without a premature progesterone elevation (Group 2) were included. The cut-off value of serum progesterone on the day of human chorionic gonadotropin (hCG) administration was $0.9 \mathrm{ng} / \mathrm{ml}$. The indication for ICSI was male factor infertility exclusively. On the day of hCG injection, serum IL-6, VEGF and bFGF were significantly higher in Group 1 $(7.7 \pm 24.5 \mathrm{pg} / \mathrm{ml}, 290.2 \pm 161.4 \mathrm{pg} / \mathrm{ml}$ and $15.7 \pm 8.2 \mathrm{ng} / \mathrm{ml}$ respectively) than in Group $2(1.7 \pm 0.7 \mathrm{pg} / \mathrm{ml}, 175.2 \pm 92.1 \mathrm{pg} / \mathrm{ml}$, and $9 \pm 1.6 \mathrm{ng} / \mathrm{ml}$ respectively). On the day of follicular puncture, serum cytokine concentrations were similar in the two groups. IL6 intrafollicular concentrations were higher in Group 1 $(14.7 \pm 20.7 \mathrm{pg} / \mathrm{ml})$ than in Group $2(9 \pm 9.3 \mathrm{pg} / \mathrm{ml}, \mathrm{p}=0.031)$. There were no differences regarding the ICSI outcome. Patients with serum progesterone above $0.9 \mathrm{ng} / \mathrm{ml}$, have elevated serum concentrations of IL-6, VEGF, and bFGF, as well as elevated intrafollicular concentrations of IL- 6 . The outcome of ICSI cycles is not associated with premature elevation of progesterone when the cut-off value is set at $0.9 \mathrm{ng} / \mathrm{ml}$.
\end{abstract}

\section{Key words}

Premature elevation of progesterone - VEGF - bFGF - Leptin • TNFa $\bullet \mathrm{IL}-1 \beta \bullet \mathrm{IL}-6$

\section{Corresponding author}

N. Nikolettos, Laboratory of Physiology, School of Medicine, Democritus University of Thrace, 68100 Alexandroupolis, Greece. Fax: +302551030504. E-mail: basima@med.duth.gr

\section{Introduction}

Premature elevation of progesterone $(\mathrm{P})$ serum concentrations is a frequent event during controlled ovarian stimulation (COS). It has been related with premature luteinization raising concerns on the impact of prematurely elevated progesterone on the outcome of in vitro fertilization (IVF) cycles.

Premature luteinization is a highly controversial clinical entity. Although it is generally accepted that, during COS, a subtle rise of serum progesterone on the day of human chorionic gonadotropin (hCG) administration is unavoidable, there is no consensus regarding either the exact definition for premature luteinization or the clinical impact of elevated progesterone. Usually, premature luteinization is defined according to serum concentration of progesterone on the day of hCG administration, although another definition based on the progesterone/estradiol ratio has also been suggested (Givens et al. 1994, Younis et al. 1998, 2001). The cut-off value of serum progesterone used to define premature luteinization is highly controversial, ranging from 0.8-2 ng/ml (Schoolcraft et al. 1991, Silverberg et al. 1991, Fanchin et al. 1993, Hofmann et al. 1993, Legro et al. 1993, Bustillo et al. 1995, Yovel et al. 1995, Hofmann et al. 1996, Shulman et al. 1996, Ubaldi et al. 1996, Chetkowski et al. 1997, Bosch et al. 2003).

Several investigators have reported reduced pregnancy rates in in vitro fertilization (IVF) cycles with a premature rise of serum progesterone (Schoolcraft et al. 
1991, Silverberg et al. 1991, Fanchin et al. 1993, Yovel et al. 1995, Shulman et al. 1996, Younis et al. 1998, 2001, Bosch et al. 2003), whereas others have shown that a premature rise of serum progesterone has no adverse effect on oocyte and embryo quality (Hofmann et al. 1993, Legro et al. 1993, Givens et al. 1994, Bustillo et al. 1995, Hofmann et al. 1996, Ubaldi et al. 1996, Chetkowski et al. 1997).

From a physiological point of view, a premature rise of progesterone may either contribute to an unfavorable follicular milieu having adverse effects on the oocyte maturation and hence embryo quality, or adversely affect endometrial receptivity.

Preliminary studies have evaluated the steroid concentrations, in relation to IVF outcome, in blood or follicular fluids from cycles with premature rise of serum progesterone. Taking into consideration that cytokines play a major role in ovarian functions, the evaluation of cytokine concentrations in cycles with a premature rise of serum progesterone is of considerable importance. The present study was focused on six cytokines due to their importance in follicular function, oocyte maturation and ovulation, as indicated by previous studies.

Vascular endothelial growth factor (VEGF) is the key mediator of angiogenesis in the ovary and the association of its expression with the proliferation of ovarian blood vessels is well established (Ferrara 2004). VEGF production is enhanced during the late follicular and luteal phase (Ravindranath et al. 1992, Shweiki et al. 1993, Unkila-Kallio et al. 2000).

Basic fibroblast growth factor (FGFb) is known as a factor exerting anti-apoptotic effects in ovarian cells of different species (Trolice et al. 1997, Hosokawa et al. 1998, Reynolds and Redmer 1998, Peluso and Papallardo 1999, Lynch et al. 2000).

Leptin, is thought to participate in the regulation of ovarian steroidogenesis, while at the same time sex steroid hormones, especially progesterone, regulate the circulating levels of leptin (Messinis et al. 1999, Caprio et al. 2001). Furthermore, a body of evidence indicates that leptin influences the outcome of in vitro fertilization attempts possibly by influencing the quality of oocytes (Mantzoros et al. 2000, Brannian et al. 2001, Tsai et al. 2002, Nikolettos et al. 2004, Asimakopoulos et al. 2005).

Several in vitro and in vivo studies have shown that proinflammatory cytokines, namely interleukins IL-1 $\beta$ and IL- 6 as well as tumor necrosis factor $\alpha$ (TNF $\alpha$ ) are implicated in reproductive functions (Zolti et al. 1990, Wang et al. 1992, Best and Hill 1995, Büscher et al. 1999, Mendoza et al. 1999, Johnson et al. 1999, Lee et al. 2000). It is also known that estrogens inhibit IL-1 $\beta$, IL-6 and TNF $\alpha$ expression, while progesterone and androgens inhibit IL-1 $\beta$ production by mononuclear cells (Hu et al. 1988, Pacifici et al. 1989). At the same time, IL-1 $\beta$ and TNF $\alpha$ have been proposed as modulators of luteinized granulosa cell function (Adashi et al. 1990, Fukuoka et al. 1992).

The purpose of this study was to test the hypothesis that premature elevation of progesterone is accompanied with a modified cytokine profile. VEGF, $\mathrm{FGFb}$, leptin and three proinflammatory cytokines: TNF $\alpha$, IL- $1 \beta$ and IL- 6 were evaluated both in serum and follicular fluids from women with and without a premature elevation of progesterone. Additionally, progesterone, luteinizing hormone (LH) and testosterone in serum samples, as well as estradiol (E2) in both serum and follicular fluid samples, were measured.

\section{Materials and Methods}

\section{Selection of patients}

Fifty intracytoplasmic sperm injection (ICSI) cycles treated in the Department of Obstetrics/ Gynecology, University Clinic of Schleswig-Holstein, Lübeck, were included in the study. Twenty-five of them had a premature rise of progesterone (Group 1). The cutoff value for progesterone was set at $0.9 \mathrm{ng} / \mathrm{ml}$ on the day of hCG administration according to previous reports (Schoolcraft et al. 1991, Silverberg et al. 1991, Fanchin et al. 1993, Givens et al. 1994, Bustillo et al. 1995, Abuzeid and Sasy 1996, Hofmann et al. 1996, Shulman et al. 1996, Ubaldi et al. 1996). A control group of another twenty-five cycles, with serum progesterone $\leq 0.9 \mathrm{ng} / \mathrm{ml}$, was selected as frequency-matched sample (Group 2) to meet the distribution of age in Group 1. All women had normal reproductive function and basal follicle stimulating hormone (FSH) levels below $10 \mathrm{mIU} / \mathrm{ml}$. The cause of infertility was the male factor, in all cases. The age of women was between 28 and 38 years. The patients gave verbal consent and did not receive any financial compensation for participating in the study. Only one cycle of each woman was included in the study.

Ovarian stimulation - ICSI - embryo transfers

COS followed the multidose GnRH antagonist protocol ("Lübeck protocol") (Diedrich and Felberbaum 1998, Felberbaum et al. 2000). Briefly, the stimulation was made with recombinant FSH (recFSH) (Gonal-F $®$, 
Serono International S.A., Geneva, Switzerland). The total dose of recFSH was individualized according to serum estradiol (E2) levels and transvaginal ultrasound measurements of the developing follicles. The pituitary suppression was made with the use of cetrorelix (Cetrotide ${ }^{\circledR}$, ASTA Medica AG, Frankfurt/Main, Germany and Serono International S.A., Geneva, Switzerland). In all cases, the induction of ovulation was made with 10000 IU hCG (Choragon $\AA$, Ferring Arzneimittel GmbH, Kiel, Germany), when there was at least one follicle with a diameter of $\geq 20 \mathrm{~mm}$ measured by transvaginal ultrasound or an E2 concentration $\geq 1200$ $\mathrm{pg} / \mathrm{ml}$. Transvaginal oocyte retrieval assisted by ultrasound monitoring was performed $36 \mathrm{~h}$ later.

Following oocyte retrieval, ICSI was performed with freshly ejaculated spermatozoa. Up to three twopronuclear (2PN) oocytes were selected in each cycle for further development and embryo transfer, while the rest were cryopreserved. One to three embryos were transferred in each cycle, in accordance with the German Law. Before the embryo transfers, a cumulative embryo score (CES) was calculated, paying attention to the degree of fragmentation and regularity of blastomeres, as described elsewhere (Asimakopoulos et al. 2002). The presence of positive fetal heartbeats was indicative of clinical pregnancies.

\section{Samples collection and measurements}

Blood serum was collected on the day of hCG administration and on the day of oocyte retrieval. Follicular fluid samples were collected on the day of oocyte retrieval. From each patient, follicular fluid samples were collected among the first one to three mature follicles containing metaphase II oocytes, they were pooled and placed into sterile tubes. All follicular fluid samples were immediately centrifuged for $15 \mathrm{~min}$ at $1500 \mathrm{rpm}$ and aliquots of the supernatants were stored. Follicular fluid samples with obvious blood contamination or mixed with flushing fluids were excluded. All materials were stored at $-20{ }^{\circ} \mathrm{C}$ until further analysis.

The levels of the total fractions of the following cytokines were measured in the serum and follicular fluid samples: IL-1 $\beta$, IL-6, TNF $\alpha$, bFGF, VEGF and leptin. E2 was measured in serum and follicular fluids. progesterone, luteinizing hormone ( $\mathrm{LH})$ and testosterone levels were measured in serum samples.

In the serum samples, E2, progesterone, $\mathrm{LH}$ and testosterone were measured with Elecsys immunoanalyzer (Roche Diagnostics, Mannheim, Germany) having the following intra- and inter-assay variation (AV): $<5 \%$ and $<10 \%$ for $\mathrm{E} 2,<3 \%$ and $<5 \%$ for progesterone, $<5 \%$ and $<7 \%$ for testosterone, respectively. All the other measurements were made with commercial enzyme immunoassay kits as follows. E2: DSL-10-4300 Active Estradiol EIA (DSL, Webster, Texas, USA), intra-AV: 3.3-4.8 \%, inter-AV: 6.5-8.2 \%, minimum detectable dose (MDD): $7 \mathrm{pg} / \mathrm{ml}$. IL-1 $\beta$ : Quantikine DLB50 (R\&D Systems Inc, Minneapolis, USA), intra-AV: $2.8-8.5 \%$, inter-AV: 4.1-8.4 \%, MDD: $1 \mathrm{pg} / \mathrm{ml}$. IL-6: Quantikine D6050 (R\&D Systems Inc, Minneapolis, USA), intra-AV: 1.6-4.2 \%, inter-AV: 3.3$6.4 \%$, MDD: $0.7 \mathrm{pg} / \mathrm{ml}$. TNF $\alpha$ : Quantikine DTA00C (R\&D Systems Inc, Minneapolis, USA), intra-AV: 4.25.2 \%, inter-AV: 4.6-7.4 \%, MDD: $0.5 \mathrm{pg} / \mathrm{ml}$. VEGF: Quantikine DVE00 (R\&D Systems Inc, Minneapolis, USA), intra-AV: 4.5-6.7 \%, inter-AV: 6.2-8.8 \%, MDD: 5pg/ml. FGFb: ChemiKine CYT142 (Chemicon Intern. Inc., USA), intra-AV: $8.2 \%$, inter-AV: $10.1 \%$, MDD: $0.488 \mathrm{ng} / \mathrm{ml}$. Leptin: Quantikine DLP00 (R\&D Systems Inc, Minneapolis, USA), intra-AV: 3-3.3 \%, inter-AV: 3.5-5.4 \%, MDD: $7.8 \mathrm{pg} / \mathrm{ml}$.

As the above kits are validated for serum samples but not for follicular fluid, before running the follicular fluid samples, we checked the recovery rate of at least three spiked follicular fluid samples and the linearity of the results after multiple dilutions. The results were satisfactory, with recovery rates ranging from $80 \%$ to $130 \%$. All samples were measured in duplicate, according to manufacturers' instructions. In cases of very high or low results, the measurements were repeated.

\section{Statistical analysis}

The normality of all studied parameters was checked with the Shapiro-Wilks' W test and an additional evaluation of kurtosis and skewness. The statistical analysis included descriptive statistics for both studied groups. The comparisons of clinical data as well as of hormonal and cytokine concentrations in follicular fluid between the groups were performed either with the t-test, or with two non-parametric tests: Mann-Whitney U-test and Kolmogorov-Smirnov. The comparisons of hormonal and cytokine concentrations in the serum were performed with two-way mixed ANOVA. Post hoc analysis was performed using Bonferroni's corrections. Rates were compared by the $\mathrm{x}^{2}$ test. Correlations were evaluated with the Spearman Rank test. The two-tailed significant level was set at $\mathrm{p}<0.05$. The software we used for statistical 
Table 1. Clinical parameters of the studied groups.

\begin{tabular}{lccc}
\hline & Group 1 & Group 2 & Two sided p-level \\
\hline Age (years) & $32.6 \pm 4.56$ & $34.29 \pm 3.09$ & 0.253 \\
Body mass index & $23.21 \pm 4.47$ & $24.6 \pm 2.8$ & 0.074 \\
Total dose of recFSH (I.U.) & $1836 \pm 533.81$ & $2002 \pm 773.05$ & 0.271 \\
No offollicles & $14.2 \pm 4.6$ & $10.12 \pm 3.93$ & $0.002^{*}$ \\
Retrieved MII oocytes (n) & $12.16 \pm 4.71$ & $7.8 \pm 4.82$ & $0.002^{* *}$ \\
Fertilization rate (\%) & $51.83 \pm 22.6$ & $56.64 \pm 26.65$ & 0.893 \\
Embryos transferred $(n)$ & $2.52 \pm 0.59$ & $2.2 \pm 0.87$ & 0.271 \\
Cumulative embryo score & $21.64 \pm 8.99$ & $18.16 \pm 10.18$ & 0.206 \\
\hline
\end{tabular}

Data are means \pm S.D. *: significant difference between the two groups as determined by Mann-Whitney $U$ test. **: significant difference between the two groups as determined by the t-test.

Table 2. Hormonal and cytokine concentrations in serum samples of the two studied groups on the day of hCG and on the day of oocyte retrieval.

\begin{tabular}{|c|c|c|c|c|}
\hline & \multicolumn{2}{|c|}{ Group 1} & \multicolumn{2}{|c|}{ Group 2} \\
\hline & $\begin{array}{l}\text { On the day of hCG } \\
\text { administration }\end{array}$ & $\begin{array}{c}\text { On the day of } \\
\text { oocyte retrieval }\end{array}$ & $\begin{array}{l}\text { On the day of hCG } \\
\text { administration }\end{array}$ & $\begin{array}{l}\text { On the day of } \\
\text { oocyte retrieval }\end{array}$ \\
\hline Estradiol (pg/ml) & $2906.52 \pm 1556.34^{\mathrm{a}, \mathrm{c}}$ & $1114.35 \pm 415.18^{\mathrm{b}, \mathrm{c}}$ & $1525.92 \pm 855.88^{\mathrm{a}, \mathrm{d}}$ & $533.92 \pm 258.22^{\mathrm{b}, \mathrm{d}}$ \\
\hline$L H(m I U / m l)$ & $1.6 \pm 1.34$ & & $1.88 \pm 1.97$ & \\
\hline Progesterone ( $\mathrm{ng} / \mathrm{ml})$ & $1.67 \pm 1.82^{\mathrm{e}, \mathrm{f}}$ & $19.69 \pm 7.48^{\mathrm{g}, \mathrm{f}}$ & $0.62 \pm 0.23^{\mathrm{e}, \mathrm{h}}$ & $6.26 \pm 3.89^{\mathrm{g}, \mathrm{h}}$ \\
\hline Testosterone (ng/ml) & $0.74 \pm 0.44^{\mathrm{i}}$ & $0.79 \pm 0.39^{j}$ & $0.41 \pm 0.15^{\mathrm{i}}$ & $0.54 \pm 0.21^{\mathrm{j}}$ \\
\hline$T N F \alpha(p g / m l)$ & $0.62 \pm 0.91$ & $3.44 \pm 5.97$ & $0.97 \pm 1.31$ & $3.32 \pm 4.06$ \\
\hline$I L 1 \beta(p g / m l)$ & $0.4 \pm 0.6$ & $0.5 \pm 1.1$ & $1.8 \pm 6.1$ & $0.3 \pm 0.05$ \\
\hline IL6 $(\mathrm{pg} / \mathrm{ml})$ & $7.7 \pm 24.5^{\mathrm{k}, 1}$ & $17 \pm 31.9^{1}$ & $1.7 \pm 0.7^{\mathrm{k}, \mathrm{m}}$ & $9.2 \pm 13.1^{\mathrm{m}}$ \\
\hline$V E G F(p g / m l)$ & $290.2 \pm 161.4^{\mathrm{n}, \mathrm{o}}$ & $382.3 \pm 225.7^{\circ}$ & $175.2 \pm 92.1^{\mathrm{n}, \mathrm{p}}$ & $362.4 \pm 173.7^{\mathrm{p}}$ \\
\hline Leptin $(\mathrm{pg} / \mathrm{ml})$ & $16034.5 \pm 17307.5$ & $17432.7 \pm 18507.9$ & $18261.2 \pm 14961.3$ & $23516.8 \pm 15552.7$ \\
\hline$b F G F(n g / m l)$ & $15.7 \pm 8.2^{\mathrm{q}}$ & $9 \pm 1.6$ & $8.6 \pm 3.1^{\mathrm{q}}$ & $12 \pm 4.4$ \\
\hline
\end{tabular}

Data are means \pm S.D. Values with the same superscript letters are significantly different as determined by ANOVA $(p<0.05)$.

analysis was STATISTICA 6.0 (StatSoft Inc., Tulsa, OK, USA). All values are presented as means \pm standard deviation (S.D.).

\section{Results}

All cycles had successful oocyte retrieval. The metaphase II (MII) oocytes aspirated in the cycles of Group 1 were significantly more numerous than those aspirated in the cycles of Group 2. The fertilization rate in both groups was similar. In Group 1, there were 6 pregnancies, whereas in Group 2 there were 8, the difference not reaching a statistically significant level. The main clinical data of the studied cycles are presented in Table 1.

The hormonal and cytokine profile in the serum samples of the two groups of patients are presented in Table 2. There were no elevations of LH above $5 \mathrm{mIU} / \mathrm{ml}$. On the day of hCG as well as on the day of oocyte aspiration, E2, progesterone and testosterone serum concentrations in Group 1 were significantly higher than in Group 2. From the day of hCG administration to the day of oocyte retrieval there was a statistically significant elevation of progesterone and a decrease of E2 serum concentrations in both groups. Patients in Group 1 presented a greater increase of progesterone levels $(p<0.001)$ and a greater reduction of E2 levels $(p<0.05)$ compared to patients in Group 2.

On the day of hCG, the concentrations of both VEGF and IL-6 in Group 1 were significantly higher than in Group 2. From the day of hCG to the day of oocyte 
Table 4. Spearman $\mathrm{R}$ correlations between progesterone serum concentrations on the day of hCG, clinical parameters, hormonal and cytokine serum concentrations on the day of hCG.

\begin{tabular}{lcc}
\hline & Spearman R & p-level \\
\hline Age & -0.142 & 0.33 \\
Total dose of recFSH & -0.12 & 0.406 \\
No. of follicles & 0.412 & $0.003^{*}$ \\
No. of MII oocytes & 0.372 & $0.008^{*}$ \\
Fertilization rate & -0.016 & 0.912 \\
Cumulative embryo score & 0.132 & 0.36 \\
LH on the day of hCG & -0.028 & 0.848 \\
Estradiol & 0.559 & $0.00003^{*}$ \\
Testosterone & 0.581 & $0.0002^{*}$ \\
TNF $\alpha$ & -0.213 & 0.213 \\
IL-1 $\beta$ & 0.154 & 0.371 \\
IL-6 & 0.244 & 0.158 \\
VEGF & 0.325 & 0.057 \\
Leptin & -0.098 & 0.57 \\
bFGF & 0.538 & $0.031^{*}$ \\
\hline
\end{tabular}

$*$ : statistically significant $(p<0.05)$.

retrieval, the concentrations of VEGF and IL-6 were significantly increased in both groups. bFGF serum concentrations in Group 1 were also significantly higher than in Group 2 on the day of hCG.

On the day of oocyte retrieval, there were no significant differences in cytokine serum concentrations between the two groups. The concentrations of E2 and studied cytokines in follicular fluid samples are presented in Table 3. Significantly higher IL-6 follicular fluid concentrations were found in Group 1. The mean value of TNF $\alpha$ concentration was also higher in Group 1 due to several samples which had elevated TNF $\alpha$ levels. However, the difference in TNF $\alpha$ concentrations between the two groups was not statistically significant. The concentrations of the other cytokines were similar in the follicular fluid samples of both groups.

Statistical analysis showed that progesterone serum concentrations on the day of hCG positively correlated with the number of retrieved oocytes, E2, testosterone and bFGF serum concentrations (Table 4) as well as intrafollicular IL-6 concentrations $(\mathrm{R}=0.34$, $\mathrm{p}=0.027$ ). There was also a positive correlation close to statistical significance, between progesterone and VEGF serum concentrations on the day of $\mathrm{hCG}$ administration (Table 4). Similarly, the numbers of retrieved oocytes positively correlated with E2 concentrations on the day of hCG $(\mathrm{R}=0.533, \mathrm{p}=0.0001)$.
Table 3. Hormonal and cytokine concentrations (mean \pm standard deviation) in follicular fluid samples of the studied groups.

\begin{tabular}{|c|c|c|c|}
\hline & Group 1 & Group 2 & $\begin{array}{c}\text { Two } \\
\text { sided } \\
\text { p-level }\end{array}$ \\
\hline $\begin{array}{l}\text { Estradiol } \\
(\mathrm{pg} / \mathrm{ml})\end{array}$ & $797301 \pm 373452.7$ & $861331.4 \pm 334403.6$ & 0.594 \\
\hline $\begin{array}{l}T N F \alpha \\
(p g / m l)\end{array}$ & $150.3 \pm 584.1$ & $2.9 \pm 6.7$ & 0.089 \\
\hline $\begin{array}{l}I L-1 \beta \\
(\mathrm{pg} / \mathrm{ml})\end{array}$ & $2 \pm 3.7$ & $1.9 \pm 3.3$ & 0.46 \\
\hline $\begin{array}{l}I L-6 \\
(\mathrm{pg} / \mathrm{ml})\end{array}$ & $14.7 \pm 20.7$ & $9 \pm 9.3$ & $0.031 *$ \\
\hline $\begin{array}{l}V E G F \\
(p g / m l)\end{array}$ & $3404.2 \pm 1214$ & $3124.5 \pm 1672.6$ & 0.377 \\
\hline $\begin{array}{l}\text { Leptin } \\
(\mathrm{pg} / \mathrm{ml})\end{array}$ & $21649 \pm 20205.4$ & $23675.8 \pm 18283.7$ & 0.534 \\
\hline $\begin{array}{l}b F G F \\
(n g / m l)\end{array}$ & $192 \pm 113.5$ & $163.6 \pm 90.5$ & 0.36 \\
\hline
\end{tabular}

Data are means \pm S.D. $*$ : significant difference as determined by Mann-Whitney U test $(p<0.05)$.

\section{Discussion}

Several pathophysiological mechanisms have been suggested for the premature elevation of progesterone: the LH activity of administered exogenous human menopausal gonadotropins (Copperman et al. 1995, Fanchin et al. 1995), endogenous LH secretion (Check et al. 1991), high FSH doses (Ubaldi et al. 1996, Bosch et al. 2003) or the pooled secretion of progesterone from multiple mature follicles (Silverberg et al. 1991, Givens et al. 1994). Moreover, Younis et al. (1998, 2001) have reported that premature luteinization, defined as progesterone/estradiol ratio $>1$, could be an early manifestation of a low ovarian reserve.

In the present study, the stimulation was induced with recFSH and at the same time the total dose of recFSH did not differ between the cycles with and without a premature elevation of progesterone. Therefore, we have to reject gonadotropins as a potential cause of this event. Similarly, there were no elevations of the endogenous LH and statistical analysis showed there was no correlation between $\mathrm{LH}$ and progesterone values on the day of hCG. On the other hand, there were no signs of low ovarian reserve in our study population, as all women had normal function of their reproductive system, normal basal FSH levels and responded well to COS. 
The statistical analysis of our results showed that progesterone serum concentrations were positively correlated with the number of follicles and the number of MII oocytes, which more predominated in Group 1 than in the control group. Thus, it is reasonable to suggest that the premature rise of progesterone in Group 1 in this study may at least partially be attributed to the high number of mature follicles and the pooled secretion of progesterone arising from them.

Along with elevated serum concentrations of progesterone, on the day of hCG, the patients of Group 1 presented significantly higher serum concentrations of E2, testosterone, IL6, VEGF and bFGF compared to the control group (Group 2).

It is reasonable to suggest that higher amounts of E2 and testosterone were produced in Group 1 due to the higher number of follicles in this group compared to Group 2. The elevated concentrations of steroid hormones in Group 1 can clearly be attributed to the higher number of follicles in this group compared to Group 2. Moreover, statistical analysis showed a strong correlation between E2 and the number of retrieved oocytes.

Previous studies have shown that VEGF production is enhanced during the late follicular phase (Ravindranath et al. 1992, Shweiki et al. 1993, UnkilaKallio et al. 2000). It could thus be speculated that neovascularizaton (induced by VEGF) may increase the supply of steroidogenic cells with substrates, thus supporting the production of steroid hormones, including progesterone production by granulosa cells. In the present study, a correlation between VEGF and progesterone serum concentrations was found close to statistical significance level that is in agreement with the notion that VEGF facilitates the production of progesterone by granulosa cells.

Several studies have indicated an association between progesterone and bFGF in the ovary. Peluso and Papallardo (1999) reported that progesterone, acting through a putative membrane receptor, stimulates the synthesis of bFGF in small granulosa rat cells. bFGF then activates its receptors within large granulosa cells, initiating a signal transduction pathway that maintains large granulosa cell viability. On the other hand, Grasselli et al. (2002) showed that progesterone synthesis by granulosa cells from medium size porcine follicles was enhanced when these cells were incubated with various concentrations of bFGF. The association between progesterone and bFGF is further supported by the marked positive correlation between the serum concentrations of these two factors that was found in the present study.

Interestingly, the intrafollicular concentrations of VEGF and bFGF, although higher in Group 1, were not statistically different from those of Group 2. However, it has to be mentioned that our follicular fluid samples were derived from mature follicles containing MII oocytes. Actually, we do not know the levels of VEGF, bFGF and of the other cytokines in smaller follicles. In addition, follicular fluid samples were drawn after luteinization by hCG administration. Luteinization is known to cause profound changes not only in ovarian steroidogenesis but also in the production and secretion of cytokines by ovarian cells.

The concentrations of IL- 6 both in serum, on the day of hCG administration, as well as in follicular fluid samples were also higher in patients with premature elevation of progesterone compared to control ones. The statistical analysis showed a weak correlation between progesterone serum concentrations and IL-6 intrafollicular concentrations, whereas there was no significant correlation between progesterone and IL-6 serum concentrations. A previous report has indicated that IL-6 participates in ovarian steroidogenesis, while it is known that IL-6 is produced by ovarian granulosa cells of preovulatory follicles (Machelon et al. 1994), being a main mediator of inflammatory responses during ovulation (Büscher et al. 1999). For the time being, we are unable to provide a convincing explanation for the elevation of IL-6 in blood and follicular fluids of women having a premature rise of progesterone. Future studies investigating the influence of progesterone on the IL-6 production and secretion from follicular cells may elucidate this elevation.

The luteinization of follicles by hCG administration led to an increased secretion of most cytokines, in both groups. Thirty-six hours later, at the time of oocyte retrieval, there were no significant differences in cytokine concentrations between the two groups.

The results of the present study do not provide strong indications for an adverse effect of the premature progesterone rise on the oocyte development and further on the outcome of ICSI cycles because the fertilization rate and the score of the transferred embryos were similar between the two groups, while the pregnancy rate, although lower in Group 1, was not statistically different.

In summary, the present study showed that in 
normal women, following $\operatorname{COS}$ due to male factor infertility, patients with progesterone concentrations higher than $0.9 \mathrm{ng} / \mathrm{ml}$, on the day of $\mathrm{hCG}$, have also higher serum concentrations of E2, testosterone, IL-6, VEGF and bFGF compared to patients without a premature rise of progesterone. On the day of oocyte retrieval, patients with a premature rise of progesterone still have elevated serum concentrations of E2 and testosterone. The patients with a premature progesterone rise have also elevated intrafollicular concentrations of IL-6. The elevation of the above hormones and cytokines does not seem to be detrimental to the fertilization, embryo quality and pregnancy outcome of ICSI cycles.

\section{Conflict of Interest}

There is no conflict of interest.

\section{Acknowledgements}

This study was supported by DAAD and the Greek Scholarships Foundation (IKY) through the program IKYDA 2002. The authors would like to thank the following persons for technical assistance: Mr. Fransesco Curro, Mrs. Barbara Nehls and Dr.med. Maria Minou.

\section{References}

ABUZEID MI, SASY MA: Elevated progesterone levels in the late follicular phase do not predict success of in vitro fertilization-embryo transfer. Fertil Steril 65: 981-985, 1996.

ADASHI EY, RESNICK CE, PINCKMAN NJ, HURWITS A, PAYNE DW: Cytokine mediated regulation of ovarian function: tumor necrosis factor- $\alpha$ inhibits gonadotropin supported-progesterone accumulation by differentiating and luteinized murine granulosa cells. Am J Obstet Gynecol 162: 889-899, 1990.

ASIMAKOPOULOS B, NIKOETTOS N, AL-HASANI S: Outcome of cryopreserved pronuclear oocytes obtained after ovarian stimulation with either HMG or recFSH and the GnRH-antagonist cetrorelix. Reprod Biomed Online 5 : 52s-56s, 2002.

ASIMAKOPOULOS B, NIKOLETTOS N, PAPACHRISTOU DN, SIMOPOULOU M, AL-HASANI S, DIEDRICH K: Follicular fluid levels of vascular endothelial growth factor and leptin are associated with pregnancy outcome of normal women participating in intracytoplasmic sperm injection cycles. Physiol Res 54: 263-270, 2005.

BEST CL, HILL JA: Interleukin- $1 \alpha$ and $-\beta$ modulation of luteinized human granulosa cell oestrogen and progesterone biosynthesis. Hum Reprod 19: 3206-3210, 1995.

BOSCH E, VALENCIA I, ESCUDERO E, CRESPO J, SIMÓN C, REMOHÍ J, PELLICER A: Premature luteinization during gonadotropin-releasing hormone antagonist cycles and its relationship with in vitro fertilization outcome. Fertil Steril 80: 1444-1449, 2003.

BRANNIAN JD, SCHMIDT SM, KREGER DO, HANSEN KA: Baseline non fasting serum leptin concentration to body mass index ratio is prespective of IVF outcomes. Hum Reprod 16: 1819-1826, 2001.

BUSTILLO M, STERN JJ, COULAM CB: Serum progesterone at the time of human chorionic gonadotropin does not predict pregnancy in in-vitro fertilization and embryo transfer. Hum Reprod 10: 2862-2867, 1995.

BÜSCHER U, CHEN FCK, KENTENICH H, SCHMIADY H: Cytokines in the follicular fluid of stimulated and nonstimulated human ovaries; is ovulation a suppressed inflammatory reaction? Hum. Reprod 14: 162-166, 1999.

CAPRIO M, FABBRINI E, ISIDORI AM, AVERSA A, FABBRI A: Leptin in reproduction. Trends Endocrinol Metab 12: 65-72, 2001.

CHECK JH, CHASE JS, NOWROOZI K, DIETTERICH CJ: Premature luteinization: treatment and incidence in natural cycles. Hum Reprod 6: 190-193, 1991.

CHETKOWSKI RJ, KILTZ RJ, SALYER WR: In premature luteinization, progesterone induces secretory transformation of the endometrium without impairment of embryo viability. Fertil Steril 68: 292-297, 1997.

COPPERMAN AB, HOROWITZ GM, KAPLAN P, SCOTT RT, NAVOT D, HOFMANN GE: Relationship between circulating human chorionic gonadotropin levels and premature luteinization in cycles of controlled ovarian hyperstimulation. Fertil Steril 63: 1267-1271, 1995.

DIEDRICH K, FELBERBAUM R: New approaches to ovarian stimulation. Hum Reprod 13: 1s-13s, 1998. 
FANCHIN R, DE ZIEGLER D, TAIEB J, HAZOUT A, FRYDMAN R: Premature elevation of plasma progesterone alters pregnancy rates of in vitro fertilization and embryo transfer. Fertil Steril 59: 1090-1094, 1993.

FANCHIN R, DE ZIEGLER D, CASTRACANE VD, TAIEB J, OLIVENNES F, FRYDMAN R: Physiopathology of premature progesterone elevation. Fertil Steril 64: 796-801, 1995.

FELBERBAUM RE, ALBANO C, LUDWIG M, RIETHMÜLLER-WINZEN H, GRIGAT M, DEVROEY P, DIEDRICH K: Ovarian stimualtion for assisted reproduction with $\mathrm{HMG}$ and concomitant midcycle administration of the GnRH antagonist Cetrorelix according to the multiple dose protocol: a prospective uncontrolled phase III study. Hum Reprod 15: 1015-1020, 2000.

FERRARA N: Vascular endothelial growth factor: basic science and clinical progress. Endocr Rev 25: 581-611, 2004.

FUKUOKA M, YASUDA K, FUJIWARA H, KANZAKI H, MORI T: Interactions between interferon- $\gamma$, tumor necrosis factor- $\alpha$ and interleukin-1 in modulating progesterone and oestradiol production by human luteinized granulosa cells in culture. Hum Reprod 7: 1361-1364, 1992.

GIVENS CR, SCHRIOCK ED, DANDEKAR PV, MARTIN MC: Elevated serum progesterone levels on the day of human chorionic gonadotropin administration do not predict outcome in assisted reproduction cycles. Fertil Steril 62: 1011-1017, 1994.

GRASSELLI F, BASINI G, BUSSOLATI S, TAMANINI C: Effect of VEGF and bFGF on proliferation and production of steroids and nitric oxide in porcine granulosa cells. Reprod Dom Anim 37: 362-368, 2002.

HOFMANN GE, BENTZIEN F, BERGH PA, GARRISI GJ, WILLIAMS MC, GUZMAN, I, NAVOT D: Premature luteinization in controlled ovarian hyperstimulation has no adverse effect on oocyte and embryo quality. Fertil Steril 60: 675-679, 1993.

HOFMANN GE, KHOURY J, JOHNSON CA, THIE J, SCOTT RT JR: Premature luteinization during controlled ovarian hyperstimulation for in vitro fertilization-embryo transfer has no impact on pregnancy outcome. Fertil Steril 66: 980-986, 1996.

HOSOKAWA K, AHARONI D, DANTES A, SHAULIAN E, SCHERE-LEVY C, ATZ F, OREN M, VLODAVSKY I, AMSTERDAM A: Modulation of Mdm2 expression and p53-induced apoptosis in immortalized human ovarian granulosa cells. Endocrinology 139: 4688-4700, 1998.

HU SK, MITCHO YL, RATH NC: Effect of oestradiol on interleukin 1 synthesis by macrophages. Int $J$ Immunopharmacol 10: 247-252, 1988.

JOHNSON ML, MURDOCH J, VAN KIRK EA, KALTENBACH JE, MURDOCH WJ: Tumor necrosis factor $\alpha$ regulates collagenolytic activity in preovulatory ovine follicles: relationship to cytokine secretion by the oocyte-cumulus cell complex. Biol Reprod 61: 1581-1585, 1999.

LEE KS, JOO BS, NA YJ, YOON MS, CHOI HO, KIM WW: Relationships between concentrations of tumor necrosis factor- $\alpha$ and nitric oxide in follicular fluid and oocyte quality. J Assist Reprod Genet 17: 222-228, 2000.

LEGRO RS, ARY BA, PAULSON RJ, STANCZYK FZ, SAUER MV: Pregnancy: Premature luteinization as detected by elevated serum progesterone is associated with a higher pregnancy rate in donor oocyte in-vitro fertilization. Hum Reprod 8: 1506-1511, 1993.

LYNCH K, FERNANDEZ G, PAPPALARDO A, PELUSO JJ: Basic fibroblast growth factor inhibits apoptosis of spontaneously immortalized granulosa cells by regulating intracellular free calcium levels through a protein kinase C $\delta$-dependent pathway. Endocrinology 141: 4209-4217, 2000.

MANTZOROS CHS, CRAMER DW, LIBERMAN RF, BARBIERI RL: Predictive value of serum and follicular fluid leptin concentrations during assisted reproductive cycles in normal women and in women with the polycystic ovarian syndrome. Hum Reprod 15: 539-544, 2000.

MENDOZA C, CREMADES N, RUIZ-REQUENA E, MARTINEZ F, ORTEGA E, BERNABEU S, TESARIK J: Relationship between fertilization results after intracytoplasmic sperm injection, and intrafollicular steroid, pituitary hormone and cytokine concentrations. Hum Reprod 14: 628-635, 1999.

MACHELON V, EMILIE D, LEFEVRE A, NOME F, DURAND-GASSELIN I, TESTART J: Interleukin-6 biosynthesis in human preovulatory follicles: some of its potential roles at ovulation. $J$ Clin Endocrinol Metab 70: 633-642, 1994. 
MESSINIS IE, MILINGOS S, ZIKOPOULOS K, KOLLIOS G, SEFERIADIS K, LOLIS D: Leptin concentrations in the follicular phase of spontaneous cycles and cycles superovulated with follicle stimulating hormone. Hum Reprod 13: 1152-1156, 1998.

NIKOLETTOS N, ASIMAKOPOULOS B, NICOLETTOS N, EFTHIMIADOU A, MOURVATI E, DEMIREL C: Evaluation of leptin, interleukin-1 $\beta$, tumor necrosis factor- $\alpha$, and vascular endothelial growth factor in serum and follicular fluids of women undergoing controlled ovarian hyperstimualtion as prognostic markers of ICSI outcome. In Vivo 18: 667-674, 2004.

PACIFICI R, RIFAS L, MC CRACKEN R, VERED I, MCMURTRY C, AVIOLI LV, PECK WA: Ovarian steroid treatment blocks a postmenopausal increase in blood monocyte interleukin 1 release. Proc Natl Acad Sci USA 86: 2398-2402, 1989.

PELUSO JJ, PAPPALARDO A: Progesterone maintains large rat granulosa cell viability indirectly by stimulating small granulosa cells to synthesize basic fibroblast growth factor. Biol Reprod 60: 290-296, 1999.

RAVINDRANATH N, LITTLE-IHRIG L, PHILLIPS HS, FERRARA N, ZELEZNIK AJ: Vascular endothelial growth factor messenger ribonucleic acid expression in the primate ovary. Endocrinology 131: 254-260, 1992.

REYNOLDS LP, REDMER DA: Expression of the angiogenic factors, basic fibroblast growth factor and vascular endothelial growth factor, in the ovary. J Anim Sci 76: 1671-1681, 1998.

SCHOOLCRAFT W, SINTON E, SCHENKER T, HUYHN D, HAMILTON F, MELDRUM DR: Lower pregnancy rate with premature luteinzation during pituitary suppression with leuprolide acetate. Fertil Steril 55: 563-566, 1991.

SHULMAN A, GHETLER Y, BEYTH Y, BEN-NUN I: The significance of an early (premature) rise of plasma progesterone in in vitro fertilization cycles induced by a "long protocol" of gonadotropin releasing hormone analogue and human menopausal gonadotropins. J Assist Reprod Gen 13: 207-211, 1996.

SHWEIKI D, ITIN A, NEUFELD G, CITAY-GOREN H, KESHET E: Patterns of expression of vascular endothelial growth factor (VEGF) and VEGF receptors in mice suggest a role in hormonally-mediated angiogenesis. $J$ Clin Invest 91: 2235-2243, 1993.

SILVERBERG KM, BURNS WN, OLIVE DL, RIEHL RM, SCHENKEN RS: Serum progesterone levels predict success of in vitro fertilization/embryo transfer in patients stimulated with leuprolide acetate and human menopausal gonadotropins. J Clin Endocrinol Metab 73: 797-803, 1991.

TROLICE MP, PAPPALARDO A, PELUSO JJ: Basic fibroblast growth factor and N-cadherin maintain rat granulosa cell and ovarian surface epithelial cell viability by stimulating the tyrosine phosphorylation of the fibroblast growth factor receptors. Endocrinology 138: 107-113, 1997.

TSAI EM, YANG CH, CHEN SC, LIU YH, CHEN HS, HSU SC, LEE JN: Leptin affects pregnancy outcome of in vitro fertilisation and steroidogenesis of human granulosa cells. J Assist Reprod Genet 19: 169-176, 2002.

UBALDI F, CAMUS M, SMITZ J, BENNINK HC, VAN STEIRTEGHEM A, DEVROEY P: Premature luteinization in in vitro fertilization cycles using gonadotropin-releasing hormone agonist (GnRH-a) and recombinant folliclestimulating hormone (FSH) and GnRH-a and urinary FSH. Fertil Steril 66: 275-280, 1996.

UNKILA-KALLIO L, VUORELA-VERSÄLÄINEN P, TIITINEN A, HALMESMÄKI E, YLIKORKALA O: No cyclicity in serum vascular endothelial growth factor during normal menstrual cycle but significant luteal phase elevelation during an in vitro fertilization program. Am J Reprod Immunol 43: 25-30, 2000.

WANG LJ, BRÄNNSTRÖM M, ROBERTSON SA, NORMAN RJ: Tumor necrosis factor $\alpha$ in the human ovary: presence in follicular fluid and effects on cell proliferation and prostaglandin production. Fertil Steril 58: 934940, 1992.

YOUNIS JS, HADDAD S, MATILSKY M, BEN-AMI M: Premature luteinization: could it be an early manifestation of low ovarian reserve? Fertil Steril 69: 461-465, 1998.

YOUNIS JS, MATILSKY M, RADIN O, BEN-AMI M: Increased progesterone/estradiol ratio in the late follicular phase could be related to low ovarian reserve in in vitro fertilization-embryo transfer cycles with a long gonadotropin-releasing hormone agonist. Fertil Steril 76: 294-299, 2001. 
YOVEL I, YARON Y, AMIT A, PEYSER MR, DAVID MP, KOGOSOWSKI A, LESSING JB: High progesterone levels adversely affect embryo quality and pregnancy rates in in vitro fertilization and oocyte donation programs. Fertil Steril 64: 128-131, 1995.

ZOLTI M, MEIROM R, SHEMESH M, WOLLACH D, MASHIACH S, SHORE L, BEN-RAFAEL Z: Granulosa cells as a source and target organ for tumor necrosis factor- $\alpha$. FEBS Lett 261: 253-255, 1990. 